\title{
Can the Media Be Conflict Sensitive? An Analysis of Kenya and South Africa
}

\author{
John Rabuogi Ahere \\ Peace Studies, School of Humanities, Arts and Social Sciences, University of New England, Armidale, Australia \\ Email: johnahere@yahoo.com
}

How to cite this paper: Ahere, J.R. (2019) Can the Media Be Conflict Sensitive? An Analysis of Kenya and South Africa. Open Access Library Journal, 6: e5569. https://doi.org/10.4236/oalib.1105569

Received: July 1, 2019

Accepted: July 27, 2019

Published: July 30, 2019

Copyright @ 2019 by author(s) and Open Access Library Inc.

This work is licensed under the Creative Commons Attribution International License (CC BY 4.0).

http://creativecommons.org/licenses/by/4.0/

\section{(c) (i) Open Access}

\begin{abstract}
The media shapes conflicts, especially in how the conflicts are perceived and understood. In Kenya and South Africa, beset by ongoing structural conflict, the media has played crucial roles in the shaping of narratives about the actors and the drivers of conflict. This article explores the nexus between the nature and operations of media outlets and the escalation or de-escalation of political violence. This article contends that, based on the way that they are regulated, owned and editorially structured, the media in Kenya and South Africa have contributed to the escalation of political violence. Nonetheless, there are useful cases where the media have contributed to de-escalation of political violence. The tackling of political violence in both countries can be more effective if the media are embedded in holistic conflict transformation strategies implemented by government and non-governmental actors, and if media outlets understand and implement the principles and practice of peace journalism.
\end{abstract}

\section{Subject Areas}

Journalism and Communication, Sociology, Peace Studies

\section{Keywords}

Media, Political Violence, Kenya, South Africa

\section{Introduction}

In many societies where incidents of violent conflict are frequently experienced, information collection and dissemination are part of the systems that create mutual distrust between the actors in conflicts. Media workers as purveyors of information have been implicated in perpetuating viewpoints that create the political discourses that fan violent conflicts [1]. Their reporting often focuses on 
sensationalised intrigues and dynamics of the conflicts: who is winning? Who is losing? Who has better weapons? This is a strand of reporting that writers like Lee and Maslog have referred to as war journalism [2].

Puddephatt notes that the media may also contribute to the resolution of conflicts and alleviation of violence by staying independent and out of the conflicts [3]. This is a view similar to that of Lynch and Galtung, who identify with and promulgate peace journalism-an angle of journalism that focuses on the structural causes of conflicts as opposed to focusing on the gains or losses of the protagonists [4]. Peace journalism utilises conflict analysis and transformation to rationalise the concepts of balance, honest and accuracy in reporting; it focuses on the truth while remaining people and solution-oriented [5]. Peace journalism occurs "...when editors and reporters make choices-of what stories to report and about how to report them-that create opportunities for society at large to consider and value non-violent responses to conflict" [6].

How conflict is perceived is therefore largely shaped by the media. This is because according to Weidmann, many researchers, conflict management practitioners and the general public among others, rarely collect empirical data on violent conflicts (while they are still ongoing) but mostly rely on media reports [7]. This is especially the case in Africa, where many countries are pervaded by structural conflicts and where the media has played crucial roles in the shaping of narratives about the actors and the main components of the conflicts. With a focus on Kenya and South Africa, this article explores the nexus between the nature and operations of media outlets and the escalation or de-escalation of political violence. Kenya and South Africa have infamous histories of violent conflicts whose structural causes remain largely unaddressed. Both countries also have a robust local and international media.

For the purposes of this study, the media denotes the means of mass communication and includes the press, television, radio, films, recorded music, newspapers and magazines. Henten and Tadayoni remind us that the internet is an inextricable part of the media given its ability to instantaneously reach billions of people and its utility in public communication and entertainment [8].

\section{Methodology}

The information collected is from primary and secondary sources, and consists of questionnaires, interviews, conference papers and reports, research reports, policy briefs, journal articles, books, websites and other reliable publications that provide analyses of the media and conflicts in Kenya and South Africa. ${ }^{1}$

The role of the media and its relationship to conflict is analysed through the following themes: 1) frameworks that regulate the media, 2) ownership and interests behind media outlets, and 3) editorial policies. These themes arise from the author's analysis of field research data collected in Kenya and South Africa

${ }^{1}$ Due to ethical concerns, pseudonyms are used to mask identities of interviewees and questionnaire respondents. Interviews and questionnaires were conducted in Durban and Pietermaritzburg (South Africa) as well as in Nairobi (Kenya) between November 2017 and February 2018. 
and lays the ground for discussion on how the media in Kenya and South Africa escalate or de-escalate political violence.

\section{Legal and Regulatory Frameworks}

Kenya and South Africa had repressive regimes until the early 1990s. Media regulation in both countries continues to experience the aftershocks of restrictive past laws. This is against the backdrop of the tense relationships the media has with the respective governments. An examination of the current key legal and regulatory frameworks in both countries highlights factors that constrain and enable media operations.

\subsection{Media Laws and Regulation in Kenya}

The laws affecting the work of the media in Kenya exist in fragments and are found in different sections of civil and criminal laws, hence subject to varied interpretations by regulators and civil society. ${ }^{2}$

That said, the Media Council Act of 2013 and the Kenya Information and Communications (Amendment) Act of 2013 (KICA) serve as the main reference points for media operations. The former establishes the Media Council of Kenya as the body that sets media standards and regulates and monitors compliance with those standards [10]. It also establishes the Complaints Commission, which is an independent branch of the Media Council, to enforce media standards set the by the Council, and whose mandate is to arbitrate in disputes between: 1) the public and the media, 2) the government and media and 3) within the media [10].

KICA establishes the Communications Authority of Kenya (CA) which is responsible for facilitating the development of the information and communications sectors including broadcasting, multimedia, telecommunications, electronic commerce, postal and courier services [11]. KICA also establishes the Communication and Multimedia Appeals Tribunal (CMAT) which hears: 1) complaints against any publication or conduct of a journalist or media enterprise, 2) appeals against the decisions of the CA and the Media Council of Kenya, and 3) complaints by any citizen who is aggrieved by an action or decision of licensees who are telecommunications service providers under KICA [11] [12].

Wanyama argues that KICA severely restricts freedom of the press and breaches the constitutional protections granted to journalists by, for example, proposing crippling fines that do not distinguish between local and international media or large and small media houses [13]. One of the contested areas of the

\footnotetext{
${ }^{2}$ Mbek eidentifies some of these as the Defamation Act, Cap 36; the Penal Code, Cap 63; the Books and Newspapers Act, Cap 11; Copyright Act, Cap 130; Preservation of Public Security Act, Cap 57; Public Order Act, Cap 56; Film and Stage Plays Act, Cap 222; Chief's Authority Act, Cap 128; Official Secrets Act, Cap 187; Police Act, Cap 84; Armed Forces Act, Cap 199; Communication Commission of Kenya Act of 1998; Kenya Broadcasting Act, Cap 221, ICT Act of 2007 and the Media Act of 2007 [9].
} 
Media Council Act and KICA pertain to public complaints against the media and how such may be handled decisively while ensuring press freedoms and self-regulation. Does the establishment of CMAT defeat the logic of the Media Council being a self-regulating body? By hearing appeals of aggrieved parties who are dissatisfied with the rulings of the Complaints Commission, it is possible that that CMAT may overrule the supposedly self-regulating Commission [14]. For self-regulation-a global best practice among democracies-to be effective, the process has to be owned and driven by journalists and free from government interference [15].

\subsection{Media Laws and Regulation in South Africa}

The constitution of South Africa explicitly guarantees "freedom of the press and other media" unlike that of Kenya where press freedoms are not explicitly stated [16]. Limpitlaw underscores the distinction between "press" with its implication of the news media, and "other media", which could include fashion, sports, gardening or business publications or television channels, thereby protecting all media [17]. The constitution also recognises that everyone has a right to receive information, as it is an integral aspect of freedom of expression. Section 16(1(b)) of the constitution therefore protects not just the rights of audiences but also that of organisations that foster media development. Section 32(1) of the constitution provides that everyone has the right of access to any information held by the state and any information that is held by another person and that is required for the exercise or protection of any rights. This is another crucial section for media protection as it enshrines the right to access of information.

Other sections of the constitution that give protections to the media or are linked to the same include the right to administrative action (Section 33(2)), right to privacy (Section 14), freedom of religion, belief and opinion (Section 15(1)), freedom of association (Section 18) and the right to choose one's trade, occupation or profession freely (Section 22). Some of these protections are, however, subject to limitations for as long as the limitation of a right is narrowly tailored and its purpose is interrogated by a court when deciding whether or not the limitation of the right is constitutionally sound [17].

Apart from the constitution, there are legislations that generally govern the print and broadcasting media, public broadcasting and broadcast signal distribution as summarised in Table 1.

There are laws that check or present hurdles to the media. For instance, there are those that make it difficult for journalists to protect their sources in certain circumstances. ${ }^{3}$ There are also some targeted laws that prohibit the publication of certain kinds of information including, among others, identities of minors in court proceedings, obscene materials and racism. ${ }^{4}$ This is congruent with the

${ }^{3}$ These include the Criminal Procedure Act of 1977 and the National Prosecuting Authority Act of 1998.

${ }^{4}$ These include the Criminal Procedure Act of 1977, the Child Justice Act of 2008 and the Children's Act of 2005. 
Table 1. Laws that generally govern print and broadcast media in South Africa.

\begin{tabular}{cl}
\hline Law & \multicolumn{1}{c}{ Key points } \\
\hline Imprint Act, 1993 & $\begin{array}{c}\text { Requires printers of publications intended for public sale or } \\
\text { distribution to put their full name and full address in one of the } \\
\text { official languages on any such publication } \\
\text { Provides that no person may distribute any publication that } \\
\text { is printed outside of the country unless the name of the country } \\
\text { of origin is affixed to the publication }\end{array}$ \\
$\begin{array}{c}\text { Legal Deposit Act, } \\
\text { 1997 }\end{array}$ & $\begin{array}{c}\text { To preserve South Africa's documentary heritage } \\
\text { Act, 1999 }\end{array}$ \\
$\begin{array}{c}\text { Independent } \\
\text { Communications } \\
\text { Authority of South } \\
\text { Africa Act, 2000 }\end{array}$ & $\begin{array}{l}\text { Establishes and empowers the Independent Communications Authority } \\
\text { of South Africa (ICASA). ICASA is the authority that regulates } \\
\text { electronic communications, broadcasting and postal services } \\
\text { in South Africa }\end{array}$ \\
$\begin{array}{c}\text { Electronic } \\
\text { Communications } \\
\text { Act (ECA), 2005 }\end{array}$ & $\begin{array}{l}\text { Provides for a number of specific powers and functions of ICASA } \\
\text { in relation to the entire electronic communications and } \\
\text { broadcasting sectors }\end{array}$ \\
$\begin{array}{c}\text { Media Development } \\
\text { and Diversity Agency } \\
\text { (MDDA) Act, 2002 }\end{array}$ & $\begin{array}{l}\text { Creates the MDDA as a juristic person, whose main object is to promote } \\
\text { development and diversity in the media throughout the country }\end{array}$ \\
\hline
\end{tabular}

Source: Justine Limpitlaw [17].

assertions of Delaney concerning laws that were enacted during the Apartheid era and afterwards that, according to him, violate section 16 of the constitution that pertains to freedom of the press and other media [18].

\section{Ownership and Interests behind Media Outlets}

In democratic systems, the media plays a critical role in political processes. There are those, who in underscoring the power of the media, have referred to it as the fourth estate [19]. This is because they provide information that, depending on how it is packaged, influences the shaping of public perceptions on different issues and politicians [20]. It is therefore important to understand the entities and interests behind media outlets because as A. J. Liebling famously noted, "freedom of the press belongs to those who own one" [21]. Knowing the ownership and interests behind the media is useful in understanding how and why the media act in certain political situations in Kenya and South Africa.

\subsection{Ownership and Interests behind the Media in Kenya}

Until the early 1990s, the state and then ruling Kenya African National Union (KANU) party were the key players in the ownership of the dominant media outlets in addition to a few private investors who played safe in the publication of stories so as to avoid wrangles with successive authoritarian governments [22] [23]. In the last three decades, the government has issued hundreds of broadcast licences to private entities, a majority whose identities are largely indeterminate 
due to how cumbersome it is to obtain shareholding records of private entities. That said, the ownership of the major media outlets is monopolised by a few politically connected entities and influential families but spread out in many brands to cover the digital, print as well as broadcast media, as highlighted in Table 2.

Table 2. Kenya-some major media outlets and their owners/interests.

\begin{tabular}{|c|c|c|}
\hline $\begin{array}{c}\text { Media } \\
\text { outlets/companies }\end{array}$ & Key brands & $\begin{array}{l}\text { Principal owners } \\
\text { and/or links }\end{array}$ \\
\hline Nation Media Group & $\begin{array}{l}\text { Internet: Daily Nation, Nairobi } \\
\text { News, Swahili Hub, Nation Mobile, } \\
\text { Kenya Buzz } \\
\text { - TV: NTV } \\
\text { - Print: Daily Nation, The East } \\
\text { African, Business Daily, Taifa Leo, } \\
\text { Mwana Spoti }\end{array}$ & His Highness the Aga Khan \\
\hline Standard Group & $\begin{array}{l}\text { - Internet: Standard Digital } \\
\text { Entertainment, Standard Digital } \\
\text { - TV: KTN, KTN News, Bamba TV } \\
\text { - Print: The Standard, Saturday } \\
\text { Standard, Sunday Standard, The } \\
\text { Nairobian } \\
\text { - Radio: Radio Maisha }\end{array}$ & $\begin{array}{l}\text { Former president Daniel } \\
\text { arap Moi, his son Gideon } \\
\text { Moi and his former private } \\
\text { secretary Joshua Kulei }\end{array}$ \\
\hline $\begin{array}{c}\text { Royal Media Services } \\
\text { Limited }\end{array}$ & $\begin{array}{l}\text { - Internet: Citizen Digital } \\
\text { - } \quad \text { RV: Citizen TV, Inooro TV } \\
\text { Bahari FM, Sulwe FM, Chamgei } \\
\text { FM, Wïmwaro FM, Radio Maa FM, } \\
\text { Inooro FM, Musyi FM, Muuga FM, } \\
\text { Vuuka FM, Radio Citizen, Hot } 96\end{array}$ & $\begin{array}{l}\text { Samuel Kamau Macharia, a } \\
\text { former parliamentary } \\
\text { candidate with links to } \\
\text { various senior politicians }\end{array}$ \\
\hline Radio Africa Group & $\begin{array}{l}\text { - Internet: The Star, Mpasho } \\
\text { - TV: Kiss TV } \\
\text { - Print: The Star } \\
\text { - Radio: Kiss 100, Classic 105, Radio } \\
\text { Jambo, X FM, East FM, Relax FM }\end{array}$ & $\begin{array}{ll}\text { - } & \text { Patrick Quarcoo } \\
\text { - } & \text { William Pike } \\
\text { - } & \text { Tiso Blackstar Group }\end{array}$ \\
\hline $\begin{array}{l}\text { Mediamax } \\
\text { Network Ltd }\end{array}$ & $\begin{array}{l}\text { - } \text { Internet: Mediamax Digital } \\
\text { - } \quad \text { TV: K24, Kameme TV } \\
\text { - } \\
\text { - } \\
\text { Radint: People Daily } \\
\text { Milele Radio, Pilipili Radio, Mayian } \\
\text { Radio, Meru Radio }\end{array}$ & $\begin{array}{l}\text { The family of President } \\
\text { Uhuru Kenyatta }\end{array}$ \\
\hline $\begin{array}{l}\text { Kenya Broadcasting } \\
\text { Corporation }(\mathrm{KBC})\end{array}$ & $\begin{array}{l}\text { - Internet: KBC digital } \\
\text { - TV: Signet, KBC Channel } 1 \text { TV, } \\
\text { Heritage TV, Y254 TV } \\
\text { Radio: KBC Radio Taifa, KBC } \\
\text { English Service radio, Coro FM, } \\
\text { Pwani FM, Nosim FM, Minto FM, } \\
\text { Kitwek FM, Mayienga FM, Mwatu } \\
\text { FM, Mwago FM, Ingo FM, Iftiin } \\
\text { FM }\end{array}$ & Government of Kenya \\
\hline
\end{tabular}

Source: Collated from researcher's own compilation from company websites and Mbeke, Okello-Orlale, \& Ugangu and Nyanjom [23] [24]. 
With the increased trend of cross-ownership of media brands for maximisation of profit, there are strong indications that the media sector is headed towards monopoly, with the major players lobbying hard against government efforts to limit cross-media ownership [23]. In a later section of this article, there will be an analysis of how these ownership structures come into play within the dynamics of political violence.

\subsection{Ownership and Interests behind the Media in South Africa}

During the Apartheid era, the operations, ownership of and interests behind the media were extensively controlled by the state. The post-Apartheid dispensation ushered in liberalisation and diversification of the sector. However, strong influence by the state still manifests in the structure, composition, and diversity of the South African media landscape [25]. This is discernible in the aggressive pursuit of the policy of privatisation (at the expense of liberalisation) that has benefited entities and individuals close to the ruling African National Congress (ANC) party [26].

Companies that were influential during the Apartheid period have also maintained their positions in the sector. In return, they ceded some space to companies owned by or close to individuals in government or the ANC [25]. To this end, Respondent Three argues that "the news consumer in South Africa does not have variety as news is controlled by few entities [and this] can shape political perceptions" [27]. Table 3 provides a snapshot of the major media outlets and the ownership or interests behind them.

There has been a public discourse about who, from a race perspective, owns the media in South Africa. There are perceptions that the media in South Africa is mostly owned by white South Africans [29]. These perceptions fly in the face of some research findings concluding that four of the biggest media operators, i.e. eTV, Multichoice, Times Media Group and Independent Newspapers have over $50 \%$ ownership by black South Africans [28]. Nonetheless, the research findings have some limitations in that:

“...despite the legal requirement for companies to disclose their shareholders, some still insist on confidentiality. In addition, the funding of shareholder deals sometimes restricts the ability to exercise the normal rights that ownership confers. Genuine ownership requires that shareholders are able to sell their stakes and exercise their voting rights. Sometimes that's not the case, particularly in the case of BEE (Black Economic Empowerment) shareholders" [30].

Theobald, Anthony, and Makuwerere add that “...the funding mechanisms used to finance black ownership can effectively compromise ownership rights, for example when finance costs consume all the economic benefits of ownership or when loan covenants provide for the alienation of voting rights in certain scenarios" [28].

Angelopulo and Potgieter affirm that when viewed in totality, South Africa's 
Table 3. South Africa-some major media outlets and their owners/interests.

\begin{tabular}{|c|c|c|}
\hline $\begin{array}{c}\text { Media } \\
\text { outlets/Companies }\end{array}$ & Key brands & $\begin{array}{l}\text { Principal owners } \\
\text { and/or links }\end{array}$ \\
\hline Naspers & $\begin{array}{l}\text { - Internet: news 24, Netwerk 24, Daily Sun, City Press, Die Son } \\
\text { - TV: MultiChoice, SuperSport, DStv, MNet, Showmax } \\
\text { - Print: Beeld, Beeld Saturday, Witness, City Press, Die Burger, } \\
\text { Volksblad, Rapport, Son, Son op Sondag, Daily Sun, Sunday } \\
\text { Sun, Finweek }\end{array}$ & $\begin{array}{l}\text { - } \quad \text { Public Investment Corp. } \\
\text { - } \text { The Vanguard Group } \\
\text { - } \quad \text { Northern Trust Global Investments } \\
\text { - } \quad \text { Capital Research \& Management Co. } \\
\text { - } \quad \text { Dodge \& Cox } \\
\text { - } \quad \text { BlackRock Fund Advisors } \\
\text { - } \quad \text { Fidelity Management \& Research Co. } \\
\text { - } \quad \text { Old Mutual Investment Group } \\
\text { - } \quad \text { Allan Gray Ltd }\end{array}$ \\
\hline Caxton & $\begin{array}{l}\text { - Internet: MoneyWeb, The Citizen } \\
\text { - } \quad \text { Print: Citizen Daily, Citizen Saturday, Metro Citizen }\end{array}$ & $\begin{array}{l}\text { - Moolman \& Coburn Partnership and } \\
\text { concert parties } \\
\text { - Allan Gray Ltd } \\
\text { - Other public shareholders }\end{array}$ \\
\hline $\begin{array}{l}\text { Hosken } \\
\text { Consolidated } \\
\text { Investments }\end{array}$ & $\begin{array}{l}\text { - Internet: eNews Channel Africa } \\
\text { - TV: e.tv, eNCA }\end{array}$ & $\begin{array}{l}\text { - Southern African Clothing and } \\
\text { Textile Workers' Union } \\
\text { - Marcell Golding } \\
\text { - John Copelyn } \\
\text { - Other public shareholders }\end{array}$ \\
\hline Independent Media & $\begin{array}{l}\text { - Internet: IOL, My. Independent } \\
\text { Print: Business Report, Sunday Independent, Independent on } \\
\text { Saturday, Pretoria News, Pretoria News Saturday, Mercury, } \\
\text { Daily News, The Post, Isolezwe, Isolezwe ngeSonto, Isolezwe } \\
\text { ngoMgqibelo, Sunday Tribune, Cape Argus, Cape Times, The } \\
\text { Voice, Weekend Argus, Diamond Fields Advertiser }\end{array}$ & Sekunjalo Investment Holdings \\
\hline Mail \& Guardian & $\begin{array}{l}\text { - Internet: Mail \& Guardian Online } \\
\text { - Print: Mail \& Guardian }\end{array}$ & $\begin{array}{l}\text { - } \\
\text { - } \\
\text { M\&G } \& \text { share trust }\end{array}$ \\
\hline Tiso Blackstar Group & $\begin{array}{l}\text { - Internet: TimesLIVE, DispatchLIVE, Times Select, } \\
\text { BusinessLIVE, SowetanLIVE, HeraldLIVE, Rand Daily } \\
\text { Mail, TshisaLIVE } \\
\text { - TV: Business Day TV } \\
\text { - Print: Sunday Times, Daily Dispatch, Financial Mail, } \\
\text { Business Day, Sowetan, The Herald, Weekend Post }\end{array}$ & $\begin{array}{ll}\text { - } & \text { Tiso Investment Holdings } \\
\text { - } & \text { Kagiso Asset Management } \\
\text { - } & \text { Tiso Foundation Charitable Trust } \\
\text { - } & \text { Public Investment Corporation } \\
& \text { SOC Limited } \\
\text { - } & \text { Pershing Nominees Limited } \\
\text { - } & \text { Andrew Bonamour } \\
\text { - } & \text { Credit Suisse Private Banking } \\
\text { - } & \text { HKM Family Trust }\end{array}$ \\
\hline $\mathrm{SABC}$ & $\begin{array}{l}\text { - Internet: SABC News } \\
\text { - TV: SABC 1, SABC 2, SABC 3, SABC News } \\
\text { Ligio: 5FM, Good Hope FM, Ikwekwezi FM, Lesedi FM, } \\
\text { Munghana Lonene FM, Phalaphala FM, Radio 2000, RSG, } \\
\text { SAFM, Thobela FM, truFM, Ukhozi FM, } \\
\text { Umhlobo Wenene FM }\end{array}$ & Government of South Africa \\
\hline
\end{tabular}

Source: Collated from own compilation from company websites and from Angelopulo \& Potgieter as well as Theobald, Anthony, \& Makuwerere [25] [28].

media seems to have great diversity but when viewed by brand, it is evident that most outlets are dominated by between one and four companies [25]. This gives a sense of how powerful such companies are in the political landscape as will be 
discussed later on in the analysis of the role of the media in political violence.

\section{Editorial Policies}

\subsection{Editorial Policies of the Media in Kenya}

Theoretically, a code of conduct that governs the work of journalists is available. It is conformity to that code that is problematic. There is contention that the editorial policies of major media outlets in Kenya are strongly tied to safeguarding their business interests to the extent that when journalists submit their articles to newspaper editors, for example, they may be rejected or significantly altered or "sensationalised" so that they are able to sell more copies [31] [32] [33]. Even though this is understandable because they are profit-making entities, the media's role in politics is influenced by their editorial policies.

The government has remained steadfast in influencing news products of media outlets, especially using legal frameworks discussed earlier. It is noteworthy, however, that whenever the government has become exceptionally intimidating to media operations, most media houses (including some major ones) become politically conservative in their outputs. For example, since the government's belligerent shutdown of some major TV channels in January 2018, it is noteworthy that in their digital platforms, the print media affiliated to the TV channels that were shut down have been cautious in naming senior politicians in some stories related to their performances. It is therefore not uncommon to find stories with phrases such as "[a]n outgoing Cabinet Secretary who has been offered a diplomatic posting is not a happy man" or "[a] Cabinet Secretary seems uncomfortable in his docket, if the way he carries himself is anything to go by", without naming the ministers in question [34] [35]. In addition, it has become easier for the government to water down editorial independence of some major media houses. This is ascribable to the close relationship between the latter's corporate shareholders and government functionaries [23] [31]. Due to their ownership configurations, media outlets are part of complex webs of political power structures that strangle their independence and stymie laissez-faire competition in the sector [31]. Respondent Twelve sums it up thus: “...the media is a good player in terms of governance but we have seen of late [that] the media has some biasness and... derives a specific agenda. Most of the media houses in this country are not independent" [36]. Media houses have therefore been perceived to package their outputs to favour their benefactors, sponsors, advertisers, certain political interests or their owners [23] [37]. For example, there are claims that "the Nation Media Group and Standard are... pro-government, [while] Citizen is said to be pro-opposition. How true this is, is hard to tell. It is largely a question of perception" [38].

The government has also been able to use its huge advertising budget as leverage of obtaining favourable coverage. For some time, the government threatened to hold back in the buying of advertising spaces on media brands that were critical of it. Eventually, in 2017, the government banned advertising of its ser- 
vices, including tenders and job applications, in commercial media instead choosing to advertise through a government newspaper, MyGov that the government is circulating by inserting in two newspapers: The Star and People Daily [39]. As already alluded to in Table 2, the People Daily is linked to the family of the President.

Corruption has also permeated the media as it affects all cadres of media workers. Mbeke, Okello-Orlale, and Ugangu assert that "journalists, editors and owners are politically co-opted and openly show editorial bias" [23]. This situation may be exacerbated by the Media Council's contention that "only $3500 \ldots$ of the 7000 practising journalists in Kenya are registered... raising the possibility of quacks in the profession" [40].

\subsection{Editorial Policies of the Media in South Africa}

South Africa is said to have the most free media in Africa even though there are indicators that attacks on media freedoms are increasing [18] [41]. Due to the legacies of Apartheid, the society is severely fractured by issues that oscillate around ethnicity, race, class and political affiliations. The way the media projects these issues has therefore come under scrutiny.

The intricate relationships between high-level politicians and the few large conglomerates that control most of media brands in South Africa have affected editorial independence. The SABC's editorial policies have been greatly influenced by government with opposition parties frequently calling for it to stop favouring the ANC in its coverage [42]. Other media outlets in which government functionaries have linkages with the corporate shareholders have also felt pressured to package their outputs conservatively. For the entire media fraternity, the ruling ANC has, since 2007, had a Sword of Damocles hanging over them. This is in the form of prolonged discussion on the feasibility of introducing a bill to create a Media Appeals Tribunal, which would be accountable to parliament [43]. This debate to some extent influences the outputs of media houses, which must continue to act in a manner that justifies why they should be left to self-censor at the very least, or at most, remain within the current regulatory frameworks where the independent Press Council of South Africa (PCSA) plays the role of adjudicating disputes between the media and complainants. The debate on the feasibility of the Tribunal is in the wake of allegations that in light of the ANC's dominance of national politics, the commercial press acts like a political opposition, especially since many journalists are identified with opposition parties [44]. The ANC has also expressed lack of faith in the PCSA amid allegations that it (PCSA) is biased in favour of the press [45].

Against the background of divergence in perception of media ownership in South Africa, there is postulation that because a significant segment of the media in South Africa is mainly controlled by entrepreneurs from the minority white South African population, media outputs reflect narratives that suit the maintenance of the economic status quo, especially when it comes to contentious is- 
sues such as land reforms [46] [47] [48]. Respondent Seven for example took special exception to how the Black Monday protests ${ }^{5}$ in 2017 featured prominently in the media; he felt that the high number of murders of black South Africans that occur daily were being minimised and made to look "normal" [29]. His opinion is underscored by the claims of Julius Malema, the leader of the Economic Freedom Fighters (EFF) party, "that eNCA perpetuates white supremacy" [50].

Amid the aforementioned dwindling editorial independence, there are some media practitioners and journalists who are "... basically complaining and protesting" that they "... cannot be told what to do with [in] the media" [51]. Theirs are, however, voices that are increasingly being drowned in the quicksand created through the connivance of politicians and media owners.

\subsection{International Media Brands in Kenya and South Africa}

International media brands are accessible in both countries directly via satellite and/or internet, as well as through media brands incorporated in both countries. These international brands include the Cable News Network (CNN), National Geographic, Al Jazeera, the British Broadcasting Corporation (BBC), Sky News, Bloomberg, Euronews, France24 and Reuters among others.

The extent of their impacts on the political perceptions of consumers in Kenya and South Africa is linked to the wriggle room provided by the respective licensing and accreditation procedures in both countries. Just like their local counterparts, international journalists are required to be registered and/or accredited by the respective regulatory institutions i.e. the Media Council of Kenya [10] and the Directorate of Media Engagement of the government of South Africa [52]. Depending on the nature of any of the two states' relations with international media at a particular time, it is not beyond the realm of possibility that as a defensive measure, a government may seek to limit the numbers of foreign journalists through the accreditation process. For example, in both countries the application for accreditation by an international journalist requires that they have a valid work permit, which can be cumbersome to obtain should officials create bureaucratic bottlenecks to frustrate international media generally or target specific brands.

That said, the ability of international media brands to influence how a country's political stability and business environment are perceived locally and internationally cannot be overstated. For example, how the international media emphasises the potential for political violence when reporting on general elections in Kenya has influenced the fluctuation of numbers of tourists visiting the country, impacted on the performance of the Nairobi Stock Exchange and shaped the postures towards Kenya by other governments and entities internationally [53]. In South Africa, the manner in which the international media packages stories

${ }^{5}$ On 30 October 2017, protesters (mostly white South African farmers) wore black clothing and gathered across motorways in Cape Town, Pretoria and Johannesburg in processions of tractors and trucks to protest against what they perceived as weak state response to "farm murders" which allegedly targeted white commercial farmers [49]. 
and reports on the country or the government has variously contributed to loss of investor confidence, lowering of international credit ratings and recession of the mining sector followed by redundancies [54] [55]. This, in addition to other domestic political factors, helped to shape the broad perception that the country needed a change of leadership_as happened when President Jacob Zuma was, in February 2018, forced by the ANC to resign. This was against the backdrop of allegations that dominant narratives had been furthered by Western nations and media outlets focusing more on him as the source of the country's socio-economic woes and less on structural problems in the country [56] [57].

On the whole, the rationale for and ability of international media brands to control narratives are hinged on the fact that they are owned or controlled by powerful states on the one hand (e.g. United Kingdom and BBC) and influential families on the other (e.g. Rupert Murdoch and Fox News) [22]. This provides huge potential for the shaping of public perception, policy and political processes in favour of certain governments, big business, ideological platforms, and political parties among other entities that are closely associated with international media brands, and who stand to gain or lose from the shift or maintenance of an existing socio-economic and political status quo. Put in another way, global political elites "manufacture consent" package their media outputs in order to develop and sustain compelling narratives that help to create or maintain policies that are favourable to them (the aforementioned political elite) [60].

So far this article has examined some themes that help in understanding the nature of operations of the media in Kenya and South Africa. In the next sections, the article examines how, based on the interplay of the aforementioned themes, the media plays a role in political violence.

\section{The Media and Political Violence}

Based on how they package their outputs, the media may escalate or de-escalate political violence. Media houses may, for example, feel that they are achieving a balance in reporting views of their owners-cum-political elite on a set of issues. They may, however, not only overlook the fact that that their reporting may make people discordant, but also the reality that the populace may have other sets of issues that are more important to them [61]. Analysis of some dynamics of media outputs in the often politically-charged contexts of Kenya and South Africa suggests some parallels between both countries.

\subsection{How the Media Can Escalate Political Violence}

\subsubsection{The Kenyan Situation}

The 2007/2008 post-election violence (PEV) continues to be used as a yardstick

${ }^{6}$ In their works on the media and propaganda, Herman and Chomsky argue that media outlets are powerful entities in any political process because they play a role in fronting ideological positions which are implanted in the minds of media output consumers without the need for overt coercion [58]. Manufacturing of consent therefore comes about when agreement is brought about on the part of the public for things that they didn't want by the new techniques of propaganda [59]. 
of how quickly political violence can escalate. In his study that sampled 373 residents of Uasin Gishu County, Chebii found that the media played a role in escalating the $2007 / 2008$ PEV [62]. His findings reveal that $70 \%$ of the respondents confirmed that the media escalated the 2007/2008 PEV. This article's author also conducted field data collection in Nairobi in January and February 2018, wherein he interacted with 24 respondents who were purposively sampled. Eighty-three percent of the respondents confirmed that the media contributes to disagreements witnessed within political parties. There are some reasons for the responses in these findings.

The media has been accused of dividing society through some of their outputs. This has happened mostly through sensational reporting without regard to conflict sensitivity. For example, there have been cases where TV stations broadcast images of victims of violence and, in the commentary, underscored that the victims and assailants were from different ethnic groups that have violently clashed in the past. This has led to escalation of violence by different groups who react on the notion that “...they are killing our people!" [32] [33].

The handling of hate speech has also been problematic for the media. This has been the case when media outlets air and print, in their raw form, incendiary rhetoric made by politicians. Respondent Eleven [38], in a view shared by Gathara [63], contends that, in such instances, the media becomes an accessory to the hate speech crimes committed by such politicians because the effect of such speeches would be reduced if the media acted responsibly by self-censoring.

The media has also been accused of being partisan in political reporting in a country that is fractured politically along ethnic lines. These accusations have originated from government, opposition politicians and consumers of media outputs. For instance, Respondent Twelve [36] and The Star Reporter [64] argue that at the heart of the political crisis in January 2018, the mainstream media sustained, among others, the narrative that there were divisions in the National Super Alliance (NASA) coalition to the extent that NASA leaders threatened to ask their supporters to boycott Nation Media Group's products. At around the same period, the government cited a "serious breach of security" and shut down KTN, NTV and Citizen TV after they defied government warnings not to provide live broadcast of the symbolic "swearing in" ceremony of NASA leader Raila Odinga as "the people's president" following the disputed August 2017 general elections [65] [66]. Even though the government's actions were heavily criticised locally and internationally, some Kenyans were not concerned and, due to their perceptions of media bias, explained on social media platforms that "...you guys [the affected media] went to bed with the government so we don't really miss your news. If we want anything, we go to the internet” [38].

\subsubsection{The South African Situation}

In examining the extent to which the media causes fractures within political parties, the author of this article interacted with 22 respondents who were purposively sampled in Durban and Pietermaritzburg. In the findings, $73 \%$ of the res- 
pondents indicated that the media was partly responsible for fomenting conflicts within political parties. This is against the backdrop of the fact that in recent years, intra-party violence has been on the rise in South Africa [67].

One of the reasons why political violence has been attributed to the media is because of allegations that they tend to focus more on divisive negative issues affecting society rather than on things that could unite a people who remain splintered by the legacies of Apartheid [68]. For example, Respondent Six points out that the media has failed to cover positive work of politicians like Hlengiwe Mgabadeli, who offered bursaries that enabled her (the respondent) and many other needy students to go through high school and college, but instead focused on negative stories fronted by her (Hlengiwe's) detractors [69].

Another accusation that has been levelled against the media is that they often take sides in the reporting of contentious political issues. There are media brands like the Daily Maverick and eNCA news channel that have been identified to be biased against the ANC and others like ANN7 and SABC TV that project the government or some of its functionaries in positive light even when they are riddled with scandals [27] [41] [70] [71].

There are also assertions that the media has not been able to find a proper balance between factual reporting and contextualising the matters they report on [70] [72]. Giving a context to a story can make the difference in avoiding violence, especially in flashpoint areas such as Richmond in KwaZulu-Natal that is prone to political killings. For instance, there are some media outputs that have reported high profile murders as political killings without necessarily underscoring the fact that they may also actually be criminally motivated murders or those associated with business rivalry, especially in the taxi industry [51] [73]. Respondent Seven attributes this poor contextualisation of news stories to lack of transformation in the media industry that has seen editors, most of whom are white South Africans, alter stories submitted by black South African reporters who may know more about how to shape stories so as to factor the sensitivities of "their" communities to some issues such as racial discrimination and land distribution [29]. Such editorial alterations may sell more copies of newspapers, but may also escalate conflicts in flashpoint areas. This editorial practice may also be attributed to the fact that "people will buy more bad news than good news. So now the media will report on what people want because they are trying to make profit" [69].

\subsection{How the Media Can De-Escalate Political Violence}

\subsubsection{The Kenyan Context}

In their analysis of the actors that played a role in the 2007/2008 PEV, Onyebadi and Oyedeji found the media to have played functional roles in de-escalating conflicts as well as acting as society's moral witnesses since they did not just "objectively watch and report" on the violence, but they also made effort to ensure that how they reported contributed to a sense of urgency in the society about the need for the violence to end [74]. They single out The Standard and 
Daily Nation newspapers. They argue that both allocated $50 \%$ of their front page news to highlighting local and international initiatives and calls for peace in the country while their reports about ongoing violence took $31 \%$ of space with a focus on the need for the country to return to normalcy [74].

The media can and has been a useful tool that provides safe spaces for politicians with divergent views to debate issues in a constructive manner and by extension, give their (politicians) supporters the opportunity to have a better understanding of governance and how democracy works [75] [76]. A case in point was the premier of live TV debates among presidential hopefuls ahead of the 2013 general elections. The debates have since played an important role in minimising ethnic and personality-based politics while emphasising nonviolent, issue-based electoral competition [77]. They also help in improving governance by increasing the citizenry's knowledge of complex issues in governance.

The media has also been useful in aiding conflict early warning and early response in Kenya. Its role in this was felt most during the 2013 general elections period when, after gauging the mood in the country, "they [feverishly] preached peace and put journalistic ideals aside for sake of stability..." [78]. However, critics of this strategy argue that it contributed to the wrongful selling of narratives in the country that have equated peace to the absence of violence [79]. This may counteract peacebuilding efforts that seek to identify and tackle structural problems.

\subsubsection{The South African Context}

Given that South Africa's political context is one that largely respects the constitutionally enshrined freedoms of the press, the media is a crucial platform for ventilating the joys, emotions and frustrations of South African citizens. This is a crucial function in the South African society, which has serious socio-economic inequalities. For example, the extensive cross-media coverage and analysis of the 2015 \#FeesMustFall protests may have prevented the protest's leaders from calling for more militant action by protesters because their messages were being heard by policymakers and publicly debated through the media.

Closely related to the aforementioned is the role of the media in working on the attitudes and opinions that shapes people's behaviour towards sustaining peacebuilding. The media in South Africa has on occasion, motivated people to participate in unifying community events and those that are in the public interest. An example is found in how extensively most media outlets with national outreach covered the Moerane Commission of Inquiry into Political Killings in KwaZulu-Natal province. The coverage alerted citizenry to the endemic nature of the problem of political killings and galvanised political leaders to not only participate in the hearings, but also call on their supporters to eschew violence [70]. This has served to help generate a critical mass of political will that makes peacebuilding possible.

The media has acted as a mediator of extreme positions on reconciliation especially when conflicting parties are not able to meet directly and exchange 
views on contentious issues. This was most notable in the first few years after the end of Apartheid when the country was grappling with how to reconcile different groups that continued to be suspicious of each other. Media initiatives such as the Upbeat monthly magazine, "Peace Radio" programme and "Peace Café" TV programme contributed to the impact of peace messages between different ethnic/racial groups by structuring their outputs so as to "facilitate peace, reconciliation, reconstruction, and tolerance" [80].

\section{Lessons Learnt}

This article set out to explore the nexus between the nature and operations of media outlets and the escalation or de-escalation political violence in Kenya and South Africa.

The constitutions of both countries have enshrined freedom of expression. However, the South African constitution explicitly underscores freedom of the press and this points to the importance placed on the agents of the media in the exercise of their duties. Based on this, linkage can be made to how media freedoms are generally respected-even by government-in South Africa, while in Kenya, the media has become susceptible to assault by those they cover, including government. Kenyan lawmakers should revisit the Kenya Information and Communications (Amendment) Act of 2013, especially the establishment of the Communication and Multimedia Appeals Tribunal due to how it is likely to strangle self-regulation of the Media Council. For South Africa, there is a need to examine some Apartheid laws that continue to be used as enacted or those that have been amended more recently but still contain restrictions on free expression [18]. An emasculated media is a liability to democracy, governance and conflict transformation.

Cross-ownership of the media in both countries has given majority control of this important industry to a few entities who are also well-connected to the political establishments. This has resulted in the media continuing to primarily serve the interests of the dominant elite and made the media susceptible for use in political propaganda [58] [59].

Based on the ownership structures, the editorial policies of the mainstream media in Kenya and South Africa are therefore a reflection of the interests of the owners. Such interests are at odds with conflict transformation since they aim to maintain the socio-economic and political status quo. This is against the backdrop of both countries experiencing violent conflicts whose root causes are socio-economic and political inequalities. Based on the editorial policies, media outputs have escalated political violence.

The media has also played a role in de-escalating conflicts in both countries. Crucial among the roles is the provision of spaces and channels that enable expression between and among politicians and different political groupings. Essentially, when spaces are availed to citizenry to ventilate their emotions, it reduces the chances that they will, by default, resort to violence in order to be heard [81]. 


\section{Conclusion}

Based on the way that they are regulated, owned and editorially structured, the media in Kenya and South Africa have contributed to the escalation of political violence. Nonetheless, there are useful cases where the media have contributed to de-escalation of political violence. These cases provide benchmarks that can be used to improve media outputs and increase the media's viability as a crucial actor in conflict transformation. Ultimately, the tackling of political violence in both countries can be more effective if the media are embedded in holistic conflict transformation strategies implemented by government and non-governmental actors, and if media outlets understand and implement the principles and practice of peace journalism.

\section{Acknowledgements}

The author wishes to thank Dr. Marty Branagan and Dr. Rebecca Spence, both of the University of New England, Armidale, New South Wales, Australia, for their support and initial review of this paper. The author also appreciates partial financial support from the French Institute for Research in Africa (IFRA-Nairobi) which enabled more extensive field data collection in Kenya.

\section{Conflicts of Interest}

The author declares no conflicts of interest regarding the publication of this paper.

\section{References}

[1] Sharp, S. (2013) Journalism and Conflict in Indonesia: From Reporting Violence to Promoting Peace. Routledge, New York. https://doi.org/10.4324/9780203095393

[2] Lee, S.T. and Maslog, C.C. (2005) War or Peace Journalism? Asian Newspaper Coverage of Conflicts. Journal of Communication, 55, 311-329. https://doi.org/10.1111/j.1460-2466.2005.tb02674.x

[3] Puddephatt, A. (2006) Voices of War: Conflict and the Role of the Media. International Media Support, Copenhagen.

[4] Lynch, J. and Galtung, J. (2010) Reporting Conflict: New Directions in Peace Journalism. University of Queensland Press, St Lucia.

[5] Lynch, J., Hacket, R.A. and Shaw, I.S. (2011) Introduction. Expanding Peace Journalism: Comparative and Critical Approaches. In: Shaw, I.S., Lynch, J. and Hacket, R.A., Eds., Expanding Peace Journalism: Comparative and Critical Approaches, Sydney University Press, Sydney, 7-32.

[6] Lynch, J. and McGoldrick, A. (2005) Peace Journalism. Hawthorn Press Limited, Gloucestershire, 5.

[7] Weidmann, N.B. (2015) On the Accuracy of Media-Based Conflict Event Data. Journal of Conflict Resolution, 59, 1129-1149.

https://doi.org/10.1177/0022002714530431

[8] Henten, A. and Tadayoni, R. (2008) The Impact of the Internet on Media Technology, Platforms and Innovation. In: Küng, L., Picard, R.G. and Towse, R., Eds., The Internet and the Mass Media, SAGE Publications, London, 45-64. 
https://doi.org/10.4135/9781446216316.n3

[9] Mbeke, P.O. (2008) Background Note: The Media, Legal, Regulatory and Policy Environment in Kenya: A Historical Briefing. BBC World Service Trust, Nairobi.

[10] Media Council Act (2013) National Council for Law Reporting, Nairobi.

[11] (2013) The Kenya Information and Communications (Amendment) Act. National Council for Law Reporting, Nairobi.

[12] Oketch, W. (2017) Opinion: Disputes Settlement Tribunal in Media Industry Now Set Up. http://bit.ly/2ARSumH

[13] Wanyama, L.L. (2015) Media Control in Kenya: The State of Broadcasting under the New Kenya Information and Communication Act of 2013. New Media and Mass Communication, 33, 17-22.

[14] Bosire, J. (2016) Laws Negate Self-Regulation of Media. http://bit.ly/2MkPtzQ

[15] Mijatović, D. (2011) Protection of Journalists from Violence. In: Hammarberg, T., Ed., Human Rights and a Changing Media Landscape, Council of Europe Publishing, Strasbourg, 21-46.

[16] (1997) Constitution of the Republic of South Africa Act. South Africa, Sec. 16.

[17] Limpitlaw, J. (2012) Media Law Handbook for Southern Africa: Volume 1. Konrad-Adenauer-Stiftung, Johannesburg, 214.

[18] Delaney, S. (2007) The Media and the Law: A Handbook for Community Journalists. Freedom of Expression Institute, Johannesburg.

[19] Schultz, J. (1998) Reviving the Fourth Estate: Democracy, Accountability and the Media. Cambridge University Press, New York. https://doi.org/10.1017/CBO9780511597138

[20] Pilger, J. (2005) Introduction. In: Pilger, J., Ed., Tell Me No Lies. Investigative Journalism and Its Triumphs, Random House, London, 13.

[21] Godwin, M. (2003) Cyber Rights: Defending Free Speech in the Digital Age. MIT Press, London, 10. https://doi.org/10.7551/mitpress/2258.001.0001

[22] Djankov, S., McLiesh, C., Nenova, T. and Shleifer, A. (2003) Who Owns the Media? The Journal of Law \& Economics, 46, 341-382. https://doi.org/10.1086/377116

[23] Mbeke, P.O., Okello-Orlale, R. and Ugangu, W. (2010) The Media We Want: The Kenya Media Vulnerabilities Study. Friedrich Ebert Stiftung, Nairobi, 7.

[24] Nyanjom, O. (2012) Factually True, Legally Untrue: Political Media Ownership in Kenya. Internews in Kenya. https://doi.org/10.13140/rg.2.1.1933.4485

[25] Angelopulo, G. and Potgieter, P.H. (2016) Media Ownership and Concentration in South Africa. In: Noam, E.M., Ed., Who Owns the World s Media? Media Concentration and Ownership around the World, Oxford University Press, New York, 986-1008. https://doi.org/10.1093/acprof:oso/9780199987238.003.0031

[26] Horwitz, R.B. and Currie, W. (2007) Another Instance Where Privatization Trumped Liberalization: The Politics of Telecommunications Reform in South Africa-A Ten-Year Retrospective. Telecommunications Policy, 31, 445-462. https://doi.org/10.1016/j.telpol.2007.05.008

[27] Respondent Three (2017) Interview with Author on 21 December. Durban.

[28] Theobald, S., Anthony, C. and Makuwerere, P. (2016) Who Owns the News Media? A Study of the Shareholding of South Africa's Major Media Companies. Intellidex (Pty) Ltd., Sandton, 6.

[29] Respondent Seven (2017) Interview with Author on 16 November. Pietermaritzburg. 
[30] Phakathi, B. (2016) SA’s Commercial News Media Is “Substantially Black-Owned”. http://bit.ly/2NkWE8e

[31] Ogola, G. (2011) The Political Economy of the Media in Kenya: From Kenyatta's Nation-Building Press to Kibaki's Local-Language FM Radio. Africa Today, 57, 77-95. https://doi.org/10.2979/africatoday.57.3.77

[32] Respondent Nine (2018) Interview with the Author on 1 February. Nairobi.

[33] Respondent Ten (2018) Interview with the Author on 5 February. Nairobi.

[34] Grapevine (2018) Did President Uhuru Give Wrong Man a Ministry Job? http://bit.ly/2w8qqX8

[35] Grapevine (2018) I Did Not Ask Uhuru to Be an Ambassador, Former CS "Rejects" New Post. http://bit.ly/2o298Xv

[36] Respondent Twelve (2018) Interview with the Author on 17 February. Nairobi.

[37] Ismail, J.A. and Deane, J. (2008) The 2007 General Election in Kenya and Its Aftermath: The Role of Local Language Media. The International Journal of Press/Politics, 13, 319-327. https://doi.org/10.1177/1940161208319510

[38] Respondent Eleven (2018) Interview with the Author on 6 February. Nairobi.

[39] Namunane, B. (2017) Government Sets Own Paper, Bans Adverts. http://bit.ly/2MFhOh0

[40] Otieno, B. (2018) Practicing Journalism without Accreditation to Be Criminalized. http://bit.ly/2MzG4VY

[41] Respondent One (2017) Interview with the Author on 27 November. Durban.

[42] Chabalala, J. (2018) SABC Inquiry: EFF Says It Was a Victim of Editorial Interference. http://bit.ly/2vo6b6K

[43] Krüger, F. (2017) Why Media Freedom Remains Fragile in South Africa. http://bit.ly/2LXwsD2

[44] Cowling, L. (2015) Media Feel Pressure as Divisions Widen on the Role of Journalists in South Africa. http://bit.ly/2Av5xKE

[45] Reid, J. and Isaacs, T. (2015) Press Regulation in South Africa: An Analysis of the Press Council of South Africa, the Press Freedom Commission and Related Discourses. Media Policy and Democracy Project, Johannesburg.

[46] Emdon, C. (1998) Civil Society and the Media. In: Duncan, J. and Seleoane, M., Eds., Media and Democracy in South Africa, Human Science Research Council, Pretoria, 195-210.

[47] Muirhead, N. (2016) A View from Outside: Is South Africa’s Media Transformed? http://bit.ly/2w6O3yN

[48] Wasserman, H. (2010) Tabloid Journalism in South Africa: True Story! Indiana University Press, Bloomington.

[49] Chung, F. (2017) South African Farmers Block Highways in "Black Monday" Protest against Farm Murders. https://goo.gl/BDEkkG

[50] Andersen, N. (2018) Malema Attacks eNCA, Says Channel's Policy Is to "Promote White Supremacy". http://bit.ly/2vsoOXb

[51] Respondent Four (2017) Interview with the Author on 27 November. Pietermaritzburg.

[52] Government Communication and Information System (2018) Communication \& Information Services to Media. http://bit.ly/2P8e0FW

[53] Koske, L.C. (2016) International Media Representation and the Tourism Sector 
Performance in Kenya: A Study of Cable News Network's Coverage of Kenya (2011-2015). Masters of Arts in International Studies Master's Thesis, University of Nairobi, Nairobi. http://bit.ly/2od0g16

[54] Staff Reporter (2009) International Media Coverage of SA Improves Despite Zuma. http://bit.ly/2o9W4z4

[55] White, R. (2015) SA’s Image Tarnished by Recent News Headlines. http://bit.ly/2MwEHqQ

[56] Mthembu, J. (2015) Media Lose Veneer of Objectivity with \#ZumaMustFall. http://bit.ly/2wqgPKD

[57] Spector, J.B. (2013) Does Jacob Zuma Really Hate the West? http://bit.ly/2PankJd

[58] Herman, E.S. and Chomsky, N. (2008) Manufacturing Consent: The Political Economy of the Mass Media. The Bodley Head Random House, London, 363.

[59] Chomsky, N. (2002) Media Control: The Spectacular Achievements of Propaganda. 2nd Edition, Seven Stories Press, New York, 12.

[60] Robinson, P. (1999) The CNN Effect: Can the News Media Drive Foreign Policy? Review of International Studies, 25, 301-309. https://doi.org/10.1017/S0260210599003010

[61] Boaz, C. (2010) Swallowing Camels: How the Media Misinterpret Nonviolent Struggles. International Center for Nonviolent Conflict, Webinar.

[62] Chebii, Z.K. (2014) The Role of Media in Conflict Management: The Case of Electoral Conflict in Uasin Gishu County, Kenya. Master of Arts (Peace \& Conflict Studies) Master's Thesis, Kenyatta University, Nairobi. http://bit.ly/2Mc7Iag https://doi.org/10.15640/jgpc.v3n2a3

[63] Gathara, P. (2017) When the Press Fails the People: A Critique of Kenya's Media. http://bit.ly/2OyLCMN

[64] The Star Reporter (2018) NASA Threatens to Boycott Nation Media Products over Unfair Reportage. http://bit.ly/2M8eoqd

[65] Burke, J. (2018) Kenya's Opposition Swears in Raila Odinga as "People's President". http://bit.ly/2w4PkWV

[66] Oyaya, C.O. and Poku, N.K. (2018) The Making of the Constitution of Kenya: A Century of Struggle and the Future of Constitutionalism. Routledge, New York, 250. https://doi.org/10.4324/9781315573533

[67] Ahere, J.R. (2018) When a Compatriot Becomes a Foe: Political Parties and Violent Elections in Kenya and South Africa. Journal of African Elections, 17, 25-48. https://doi.org/10.20940/JAE/2018/v17i1a2

[68] Respondent Two (2017) Interview with the Author on 7 November. Pietermaritzburg.

[69] Respondent Six (2017) Interview with Author on 29 November. Durban.

[70] Respondent Five (2017) Interview with the Author on 4 December. Pietermaritzburg.

[71] Dodovu, C. (2017) Gupta-Owned ANN7’s Propaganda a Big Turn-Off. http://bit.ly/2KGSLs3

[72] Respondent Eight (2017) Interview with Author on 15 November. Durban.

[73] De Haas, M.E. (2016) The Killing Fields of KZN: Local Government Elections, Violence and Democracy in 2016. South African Crime Quarterly, No. 57, 43-53. https://doi.org/10.17159/2413-3108/2016/v0n57a456

[74] Onyebadi, U. and Oyedeji, T. (2012) Newspaper Coverage of Post Political Election 
Violence in Africa: An Assessment of the Kenyan Example. Media, War \& Conflict, 4, 215-230. https://doi.org/10.1177/1750635211420768

[75] Betz, M. (2017) How Media Can Be an Instrument of Peace in Conflict-Prone Settings. Paper Presented at the Media and Conflict Prevention: A Research and Policy Roundtable, Oslo.

[76] Dalton, R.J. (2014) Citizen Politics: Public Opinion and Political Parties in Advanced Industrial Democracies. SAGE Publications, London.

[77] Moss, N. and O’Hare, A. (2014) Staging Democracy: Kenya's Televised Presidential Debates. Journal of Eastern African Studies, 8, 78-92.

https://doi.org/10.1080/17531055.2013.869929

[78] Gustafsson, J. (2016) Media and the 2013 Kenyan Election: From Hate Speech to Peace Preaching. Conflict \& Communication Online, 15, 1-13.

[79] Kenny, C. and Ahere, J. (2017) Elections Are Only Part of the Story in Kenya's History of Post-Poll Violence. http://bit.ly/2vJqZ9J

[80] Dovey, V. (1996) Exploring Peace Education in South African Settings. Peabody Journal of Education, 71, 128-150. https://doi.org/10.1207/s15327930pje7103_8

[81] Saunders, K.W. (2017) Free Expression and Democracy: A Comparative Analysis. Cambridge University Press, Cambridge. https://doi.org/10.1017/9781316771129 